\title{
Respiratory Syncytial Virus Antigen Measurement
}

National Cancer Institute

\section{Source}

National Cancer Institute. Respiratory Syncytial Virus Antigen Measurement. NCI

Thesaurus. Code C154823.

The determination of the Respiratory Syncytial Virus antigen present in a sample. 